\title{
АНАЛИЗ ПРИЧИН НЕОДНОРОДНОСТЕЙ И ВРЕМЕННЫХ ВАРИАЦИЙ РАДОНОВОГО ПОЛЯ В ЛАНДШАФТАХ ЦЕНТРАЛЬНОГО ЧЕРНОЗЕМЬЯ
}

\author{
В. В. Ильяш ${ }^{1}$, Д. В Ильяш ${ }^{2}$ \\ ${ }^{1}$ Воронежский государственный университет \\ ${ }^{2}$ ООО Инженерная геодезия и топография «ИГИТ», г. Воронеж
}

Поступила в редакцию 10 декабря 2018 г.

\begin{abstract}
Аннотация: эманирование радона горными породами в некоторых условиях представляет собой достаточно опасное явление, с которым приходится считаться при территориальном планировании и строительстве. С другой стороны это явление давно пытаются использовать в глубинном геологическом картировании для выявления структурных неоднородностей в земной коре. Однако то и другое направление сталкивается с определенными трудностями при интерпретациии результатов в силу широких вариаџий значений активности радона и множества факторов, совместное воздействие которых вызывает нелинейный характер зависимостей. Отсюда и разные оиенки эффективности применения радонового метода. В статье приводятся результать режсмного мониторинга объемной активности радона из приповерхностных грунтов на примере объектов Воронежской области. Основной вывод: каждая точка радонового поля в грунтовом массиве индивидуальна, поскольку ее особенности обусловлены в первую очередь геологическими факторами. Геоморфологические, метеорологические, биологические, техногенные и, возможно, космические факторы имеют все признаки наложенных возмущающих воздействий, что подтверждает колебательный и согласованный по фазе характер вариаций в соседних сближенных точках. Ключевые слова: радон, радоновое поле, генерачия геологическими источниками, наложенные воздействия, вариации активности радона
\end{abstract}

\section{ANALYSIS OF CAUSES FOR HETEROGENEITIES AND TIME VARIATIONS OF RADON FIELD IN THE LANDSCAPES OF CENTRAL BLACK EARTH REGION}

\begin{abstract}
: the emanation of radon by the rocks under some conditions is the sufficiently dangerous phenomenon, which it is necessary to consider with the territorial planning and the building. From other side have long ago been they attempted to use this phenomenon in the deep geological mapping for the development of structural heterogeneities in the earth's crust. However, and other direction encounters definite difficulties with the interpretation of results in view of wide variations in the values of the activity of radon and many factors, whose joint action causes the nonlinear nature of dependences. Hence and the different estimations of effectiveness in the application of a radon method. In the article the results of the regime monitoring of the volumetric activity of radon from the near-surface soils in a number of the objects of the Voronyezh province are given. Basic conclusion: each point of radon field in the ground massif is individual, since its special features are caused first of all by geological factors. Geomorphological, meteorological, biological, technogenic and, possibly, space factors have all signs of the superimposed disturbing actions, which confirms the oscillating and matched on the phase nature of variations at the adjacent contiguous points.
\end{abstract}

The keywords: radon, radon field, generation by geological sources, the superimposed actions, variation in the activity of radon

\section{1. Постановка проблемы}

Интерес к радону в разных направлениях геологии не случаен. Эманирование радона горными породами давно пытаются использовать при структурногеологическом картировании в качестве индикатора мест повышенной проницаемости: контактов, разрывных нарушений, карста, суффозии, при выявлении так называемых геопатогенных зон. Однако главную опасность радон представляет сам по себе, потому как вносит основной вклад в радиационное поле земной 
поверхности. Радон $\left({ }^{222} \mathrm{Rn}\right)$ является наиболее долгоживущим радиоактивным изотопом из всех газовых изотопов распада элементов уран-ториевого семейства, которые когда-то имели общее название «эманация». Но век жизни и его недолог - период полураспада составляет всего 91,8 часа. Экологическую опасность представляют и его твердые продукты распада, которые существуют в окружающем нас воздухе в виде радиоактивных аэрозолей, из которых только у ${ }^{214} \mathrm{Bi}$ период полураспада сравнительно длительный 21,7 лет. Радон, как тяжелый газ, способен накапливаться в подвальных помещениях, поэтому при инженерных изысканиях под строительство и реконструкцию нормативно-правовыми документами в обязательном порядке требуется либо оценка плотности его потока к поверхности из грунтов (эксхаляция), либо замеры объемной активности (ОАР) в почвенном воздухе на глубине 1 м. Первый параметр не должен пре-

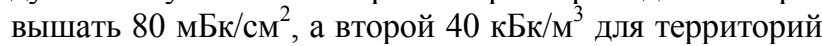
III категории потенциальной радоноопасности [1]. Нормативы для природного облучения определяют среднегодовую эквивалентную объемную активность в 100 Бк/м3 в качестве верхнего допустимого предела в воздухе для проектируемых жилых и общественных помещений и в 200 Бк/м ${ }^{3}$ для эксплуатируемых [2].

Нормативы предельно допустимых значений (ПДЗ) для оценки потенциальной радоноопасности по ОАР мы оцениваем как явно завышенные, если учесть, что верхний предел определений для радиометра радона PРА-01M составляет $20 \mathrm{\kappa Б \kappa} / \mathrm{M}^{3}$. Превышающие этот предел значения на территории Воронежской области мы зафиксировали лишь на трех объектах: в Новохоперском районе на участках восходящих глубинных минерализованных вод, на одном из циркумментов у с. Ступино Рамонского района, в с. Старая Тойда Аннинского района возле угольной котельной.

Полученные значения в почвенном воздухе обследованных нами объектов колеблются в очень широком диапазоне от 100 и более 20000 Бк $/ \mathrm{m}^{3}$. но наибо-

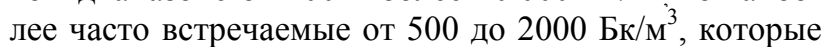
и можно принять в качестве фоновых. Также как существуют кларки отдельно для земной коры и отдельно для горных пород, следует иметь фоновые значения эксхаляции радона и для определенных фаций ландшафта. Неоднородности приповерхностного радонового поля вызываются разными факторами как природными, так и техногенными. Для оценки потенциальной радоноопасности территории и выявления геопатогенных или геоактивных зон необходимо изучение роли каждого и их интегрального воздействия. По данному вопросу имеется много публикаций, но выводы авторов весьма противоречивы [3-8]. По региону ВКМ, несмотря, на массовые замеры при инженерно-экологических изысканиях отсутствуют научные обобщения, если не считать отдельных публикаций, в которых отсутствуют фактические данные [9].

Ранее нами были опубликованы материалы, касающиеся объектов, которые изучались, в том числе, и с помощью радонового метода [10-13]. На наш взгляд, наиболее острая проблема, связана с широкими и порой неопределенными вариациями интенсивности эманирования радона грунтами. Опыт проведенных режимных мониторинговых наблюдений показывает, что они могут быть обусловлены механическим составом литологических разностей, макротекстурными неоднородностями грунтового массива, мезо- и микроформами рельефа. Влияют на них сезонность и метеоусловия. Сложность оценки роли последних в том, что их влияние происходит не сразу, а с задержкой, поскольку почвенно-грунтовая система более инертна, чем атмосфера и гидросфера. При длительном мониторинге некоторых природных объектов при кажущейся стабильности внешних условий могут проявляться некие ритмы или тренды.

Другая нерешенная проблема это глубинность источника радона, разногласия в оценке которой связаны с коротким периодом полураспада этого элемента. Скепсис в отношении самой возможности применения метода для глубинного картирования касается в первую очередь платформенных территорий с осадочным чехлом.

\section{2. Методика проведенных исследований}

Массив собранных авторских данных по эксхаляции радона составляет порядка 1000 замеров плотности потока и объемной активности на 420 точках наблюдений с помощью радиометра радона РРА 01M по методике, рекомендованной Государственной системой обеспечения единства измерений (2014г.). Замеры объемной активности радона в почвенном воздухе проводились в скважинах-шпурах диаметром 110 мм и глубиной в 1 м, пробуренных вручную вращательным способом шнековым буром, что исключало уплотнение и загрязнение грунта. Кроме того, для контроля ранее полученных результатов и развития базы данных использовался также приборный комплекс мониторинга радона «Камера 01» с программным обеспечением «Радон 98». Он позволяет одновременно производить замеры до 20 точек. Все приборы на момент замеров были аттестованы.

География точек наблюдений в авторском массиве данных в основном охватывает территорию Воронежской и Липецкой областей, частично Крыма и Адыгеи. Для режимных мониторинговых исследований в качестве объектов выбирались природные и природно-техногенные системы, участки ландшафта с различными фациальными условиями, инженерные объекты, участки проектируемого строительства. Наиболее информативные данные получены на объектах, где проводился круглогодичный или непрерывный мониторинг с поиском оптимальных технологий измерений: на разных режимах работы приборов, при разной глубине шпуров и их диаметров, с разной длительностью герметизации скважин перед замерами в разное время суток. Перед замерами активности радона фиксировались значения параметров атмосферного состояния (температура, давление и влажность) непосредственно у скважины. Обработка данных ста- 
тистическими методами проводилась с помощью компьютерных программ Excel.

\section{3. Обсуждение полученных результатов}

3.1. Вариации значений активности радона в зависимости от проницаемости (макротекстуры) грунта

Роль литологического фактора в формировании приповерхностных концентраций радона кажется достаточно очевидной. Имеют значения частные свойства горной породы или рыхлых отложений в каждой конкретной точке наблюдений. Эти свойства следует рассматривать как минимум с трех позиций: 1) вещественного состава, 2) физико-механических свойств и 3) макротекстуры исследуемого участка. Вещественный состав определяет способность породы или осадочных отложений к концентрации радиоактивных изотопов. Известно, что породы магматического щелочного ряда отличаются максимальными содержаниями радиоактивных элементов в минеральных формах, а из рыхлых отложений это глинистые и богатые органическими примесями разности. Платформенные почти мономинеральные кварцевые пески содержат радиоактивных элементов на порядок меньше, что подтверждают данные по породным кларкам [14]. Однако из наших наблюдений следует, что для осадочных пород этот фактор не играет решающей роли. Обычно наблюдается обратное - почвы на песчаных отложениях выделяют радона больше, чем на глинистых. Это можно интерпретировать как тот факт, что источник радона более глубокий, а роль подпочвен- ного субстрата лишь в обеспечении проводимости, которая зависит от содержания в нем коллоидного глинистого материала. По этому признаку глинистые грунты и делятся на тяжелые, средние и легкие. Выяснялось, что именно тяжелые суглинки более всего экранируют выделяющийся из недр радон.

Но и сам по себе механический состав отложений не всегда решающий фактор. Важнее иногда оказывается макротекстура грунтового участка, определяемая наличием свободного пространства, обеспеченного сообщающимися полостями, макропорами и трещинами. Нередко участки ландшафта, сложенные легкими песчаными суглинками, глинистыми песками, но изрытыми сурчиными норами, кротовинами, характеризуются гораздо меньшими значениями активности радона по сравнению с прилегающими участками без следов внешнего воздействия. Можно сделать вывод, что в данном случае большее значение имеет интенсивность обмена почвенного и атмосферного воздуха. По этой же причине при замерах концентрации радона в шпурах рекомендуется герметизировать их устья.

Эти выводы по важности роли макротекстурных особенностей грунтов подтверждают и результаты мониторинга-эксперимента в четырех сближенных скважинах, в двух из которых были искусственно созданы условия разной уплотненности грунта. Две скважины пробурены в ненарушенном грунте (на рис. 1 они под номерами 1м и 176), а две (72 и 73) - в насыпном. Скважина 72 пробурена в водопроводной траншее, засыпанной еще не слежавшимся черноземом,
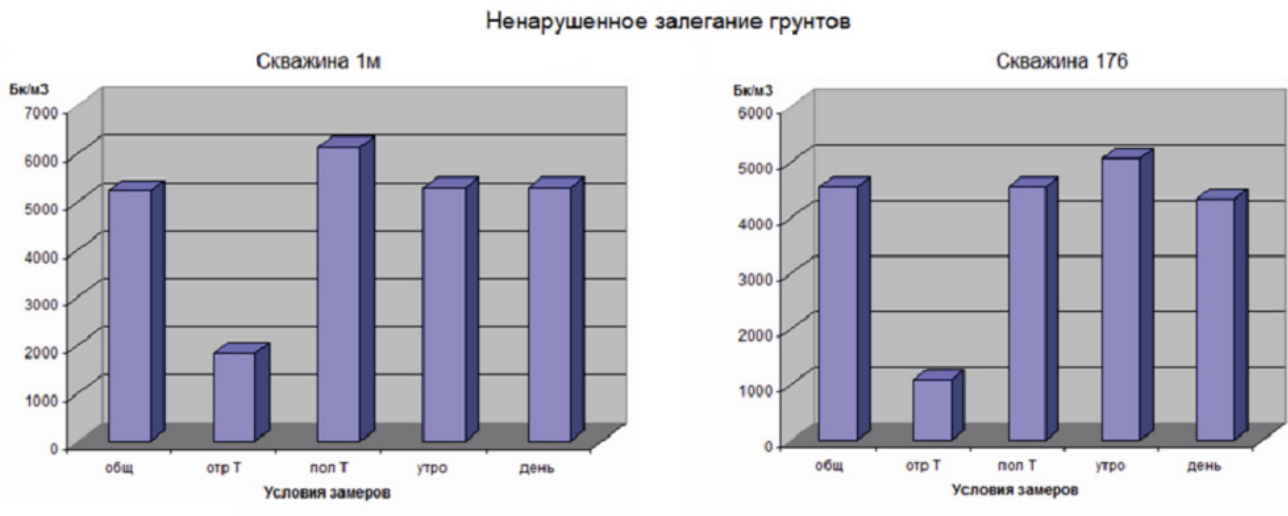

Нарушенное залегание грунтов
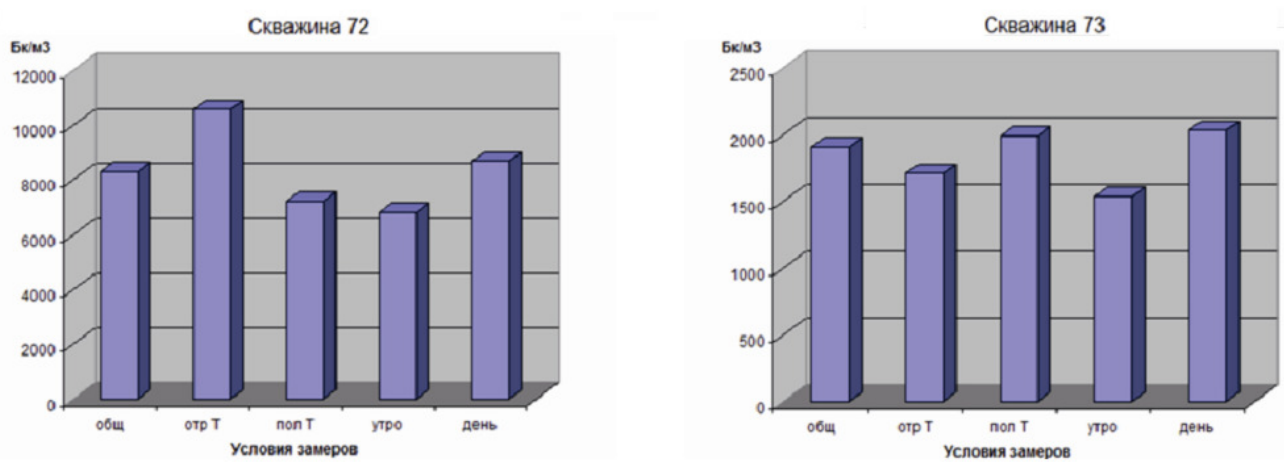

Puc.1. Гистограммы значений ОАР (общегодовые и дифференцированные по температурному режиму и времени суток) в скважинах с разной проницаемостью грунта. Сокращения: общ. - общегодовые; пол.Т - положительные температуры; отр.Т отрицательные температуры. 
а скважина 73 рядом в 4х метрах, но здесь место снятого чернозема занимает насыпной тяжелый суглинок.

В скважине 72 во все сезоны года значения объемной активности радона (ОАР) намного превосходили таковые в соседних скважинах. Более того, значения активности радона оказались здесь более высокими именно при отрицательных температурах, что необычно для нормальных условий. Возможно, это связано с тепловым эффектом воздействия зарытой в траншее водопроводной трубы. В скважине 1 м и 176 с ненарушенным грунтом, как это и свойственно мерзлым грунтам, значения ОАР были минимальными.

\section{2. Влияние механического состава подпочвенных грунтов}

Эксперимент по изучению фактора механического состава был проведен в Советском районе г. Воронежа в начале апреле 2015 года в период очень неустойчивой погоды в двух сближенных скважинах, вскрывших песчаный грунт с разным соотношением пылеватой и глинистой фракций. Скважины пробурены в сосновом массиве в 15 метрах друг от друга на одном уровне по высоте на горизонтальных площадках, что исключало влияние факторов рельефа и скопления поверхностной влаги. Участок расположен на четвертой надпойменной террасе Дона и отличается в целом повышенными значениями ОАР. Замеры снимались трижды в день утром (красные кружки на графике), днем - желтые кружки, и вечером - черные. Вариации значений ОАР в наблюдаемых скважинах оказались однотипными, хотя и разноуровенными по интенсивности (рис. 2). Разные уровни активности при прочих равных условиях связаны с различиями песков по механическому составу. По данным гранулометрического анализа пески в скв.179 оказались более тонкими и глинистыми (остаток на сите 0,05мм на 3,5 \% больше). Этой разницы вполне хватило, чтобы снизить проницаемость грунта для радона в скважине 179 более чем в два раза. Графики вариаций ОАР сходные, но явной зависимости с вариациями метеоусловий не прослеживается. Зависимость от метеоусловий лучше изучена по более представительной выборке мониторинга в скважине 1м, о чем пойдет речь ниже.

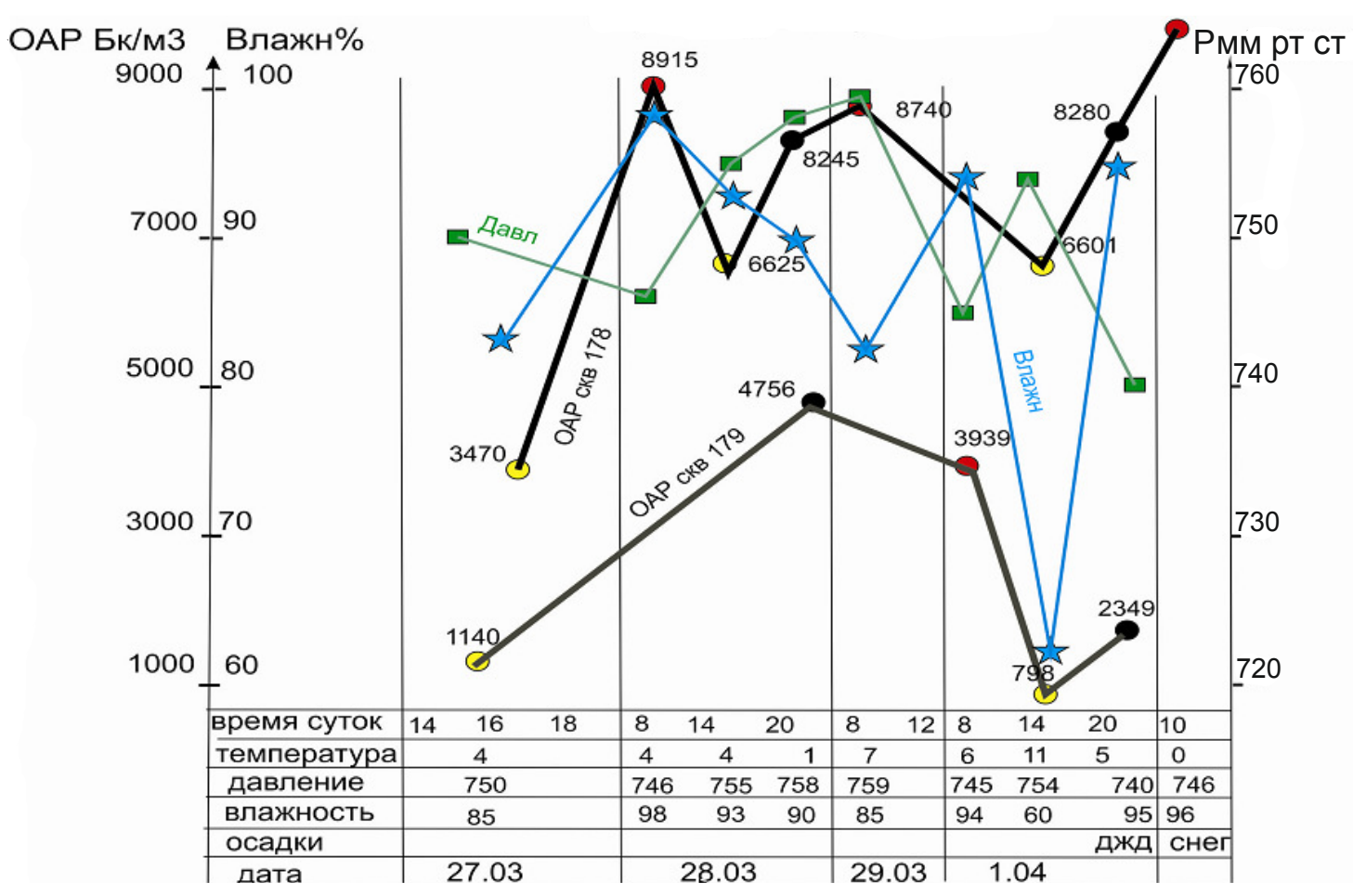

Puc. 2. Разные уровни вариаций значений ОАР в песках разной глинистости. Воронеж ул. Перхоровича. Нижний график ОАР (скв.179) соответствует более глинистым пескам.

\section{3. Метеоусловия и объемная активность радона в почвенном воздухе}

В период с 30 августа 2015 по 21 марта 2016 в скважине 1м на территории школы в с. Старая Тойда велся мониторинг ОАР для выяснения связи с параметрами атмосферного состояния (рис. 3, 4а). Выяснилось, что логарифмические линии трендов более близки между ОАР и температурой при значении коэффициента парной корреляции равным 0,44, а между
ОАР и атмосферным давлением он составлял всего 0,25 . В летнее время значения ОАР однотипно менялись в течение суток (рис. 2a). В разных технических режимах измерения значения ОАР были минимальны утром, а максимума достигали днем к 15-16 часам, ближе к вечеру постепенно снижались. Это связано с прогревом почвы в течение дня. Влага, которая накапливается в порах в ночные часы, связывает часть радона. Известно, что растворимость газа в воде с ростом 

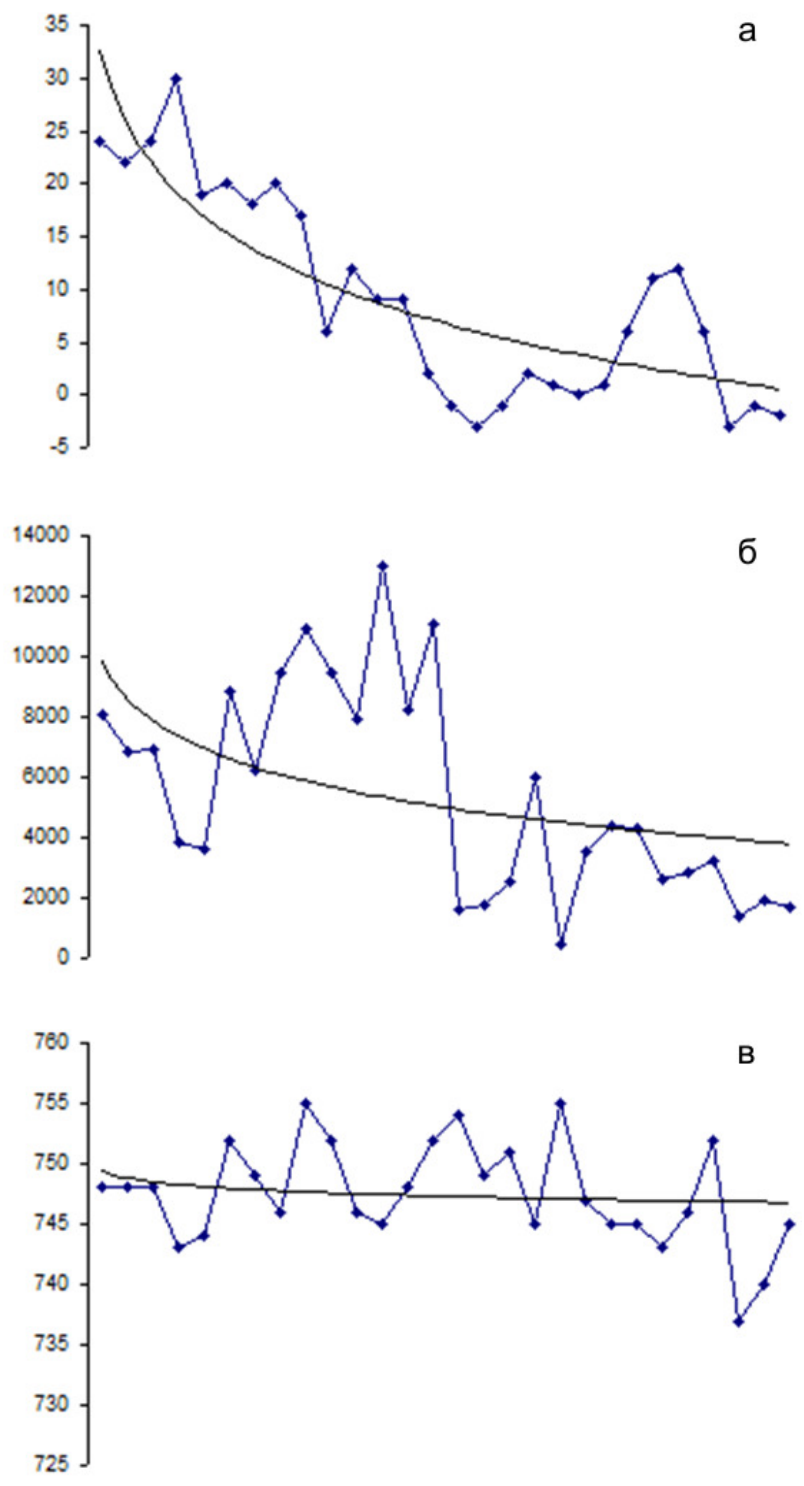

Рис. 3. Графики вариаций ОАР и параметров метеоусловий и логарифмические линии трендов. Мониторинг в скважине № 1 в период с 30 августа 2015 г. по 21 марта 2016 г. в Старой Тойде: $a$ - температура в ${ }^{\circ} \mathrm{C} ; \sigma$ - объемная активность радона (в Бк/м³ $) ;$ в - давление (в мм рт. столба).

температуры уменьшается, да и сама влага в верхних слоях почвы в летние жаркие часы быстро испаряется.

В холодные периоды года при отрицательных температурах замеры в разное время суток на вариациях ОАР особенно не сказывались. А вот периоды устойчивых потеплений согласовано сопровождались ростом ОАР во всех трех наблюдательных скважинах (№oo 72, 73, 176). Этот тренд некоторое время продолжался и после наступления новой волны холода с понижением температуры воздуха до $10^{\circ} \mathrm{C}$ (рис. 2б). Рост значений ОАР происходит на фоне незначительного повышения давления и более заметном снижении влажности воздуха. При этом температура менялась по синусоиде - сначала росла, затем через ноль вновь падала до отрицательных значений. Менее чувствительным к атмосферным изменениям оказался участок с насыпным глинистым грунтом (скв. 73), а более восприимчивым рыхлый насыпной грунт чернозема, которым была засыпана траншея с водопроводом.

Мониторинг скважин с ненарушенным почвенным профилем показывает, что в зимний период с глубоким промерзанием грунта концентрация (активность) радона в скважине становится минимальной.

\section{4. Зависимость активности радона от рельефа}

Для выяснения роли фактора мезорельефа были пройдены несколько профилей от водоразделов до русла отдельных крупных водотоков. Они проводились в Аннинском районе через долину р. Тойда по ряду маршрутов: вдоль автотрассы Анна - Бобров, а также ниже по течению р. Тойды, и через водораздел между реками Анна и Тойда (рис. 5).

Роль рельефа оценивалась и при изучении эманации радона на площадях геодинамически активных объектов, о чем предполагается сделать сообщение в последующей статье.

Водоразделы и приречный склон на территории областей ВКМ как правило покрыты покровными и моренными суглинками. Инфильтрационные процессы на плоских водоразделах снижают проницаемость подпочвенных отложений. Значения ОАР поэтому в этой части профиля оказываются невысокими, хотя и достаточно выдержанными (обычно

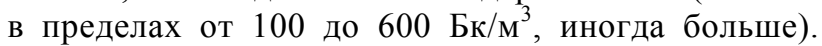
Ближе к подножию склона, где начинает скапливаться более рыхлый делювиальный материал, значения ОАР возрастают до 800-1000 Бк/м³. В долинах рек эти значения возрастают еще более до 1500-2000 Бк/м ${ }^{3}$ (рис. 5). Такой характер пространственного распределения эманации по местоположениям может быть связан с различиями возраста отложений, различиями характера протекающих процессов литогенеза. Аллювиальные отложения в пределах долин более крупнозернистые и менее уплотненные. Приведенные цифры близки к фоновым значениям для районов широкого развития в приповерхностной зоне песчано-глинистых отложений. На мелах эти значения ниже, потому что, хотя с поверхности они и трещиноваты, но с глубиной трещины довольно быстро становятся закрытыми. К тому же карбонатные породы в целом бедны радиоактивными изотопами.

Таким образом, роль мезоформ рельефа проявляется всё-таки через литологические особенности покрывающих его отложений, хотя и не всегда. Известно, что долины крупных водотоков закладываются по наиболее легко размываемым участкам ландшафта, а таковыми чаще всего являются зоны динамического влияния разломов. В подобных случаях литологический фактор уходит на второй план, а значения активности могут быть очень высокими. Это же распространяется и на участки развития карста и суффозии, что было показано нами ранее [10]. 


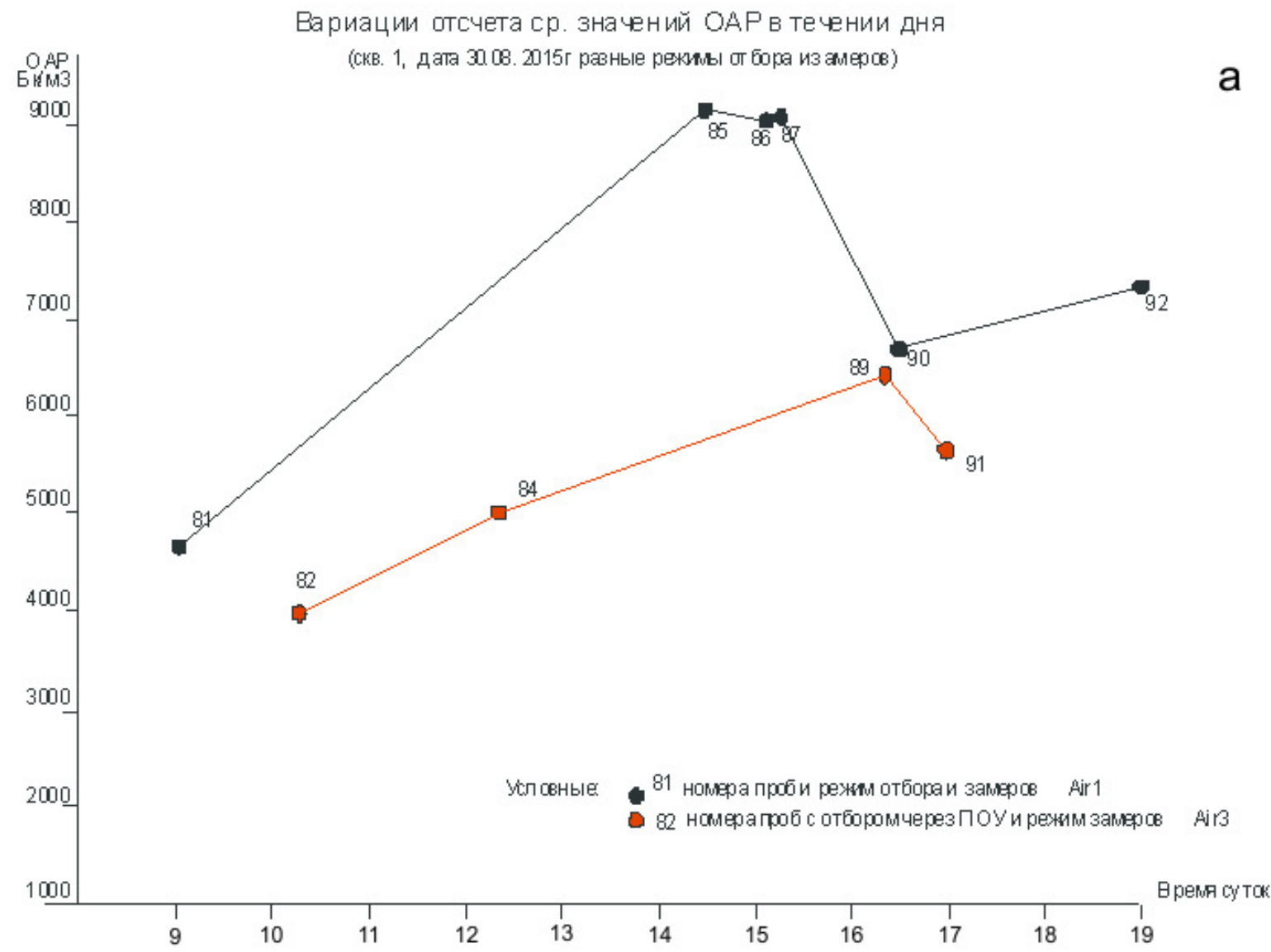

Q Ek/M3

6

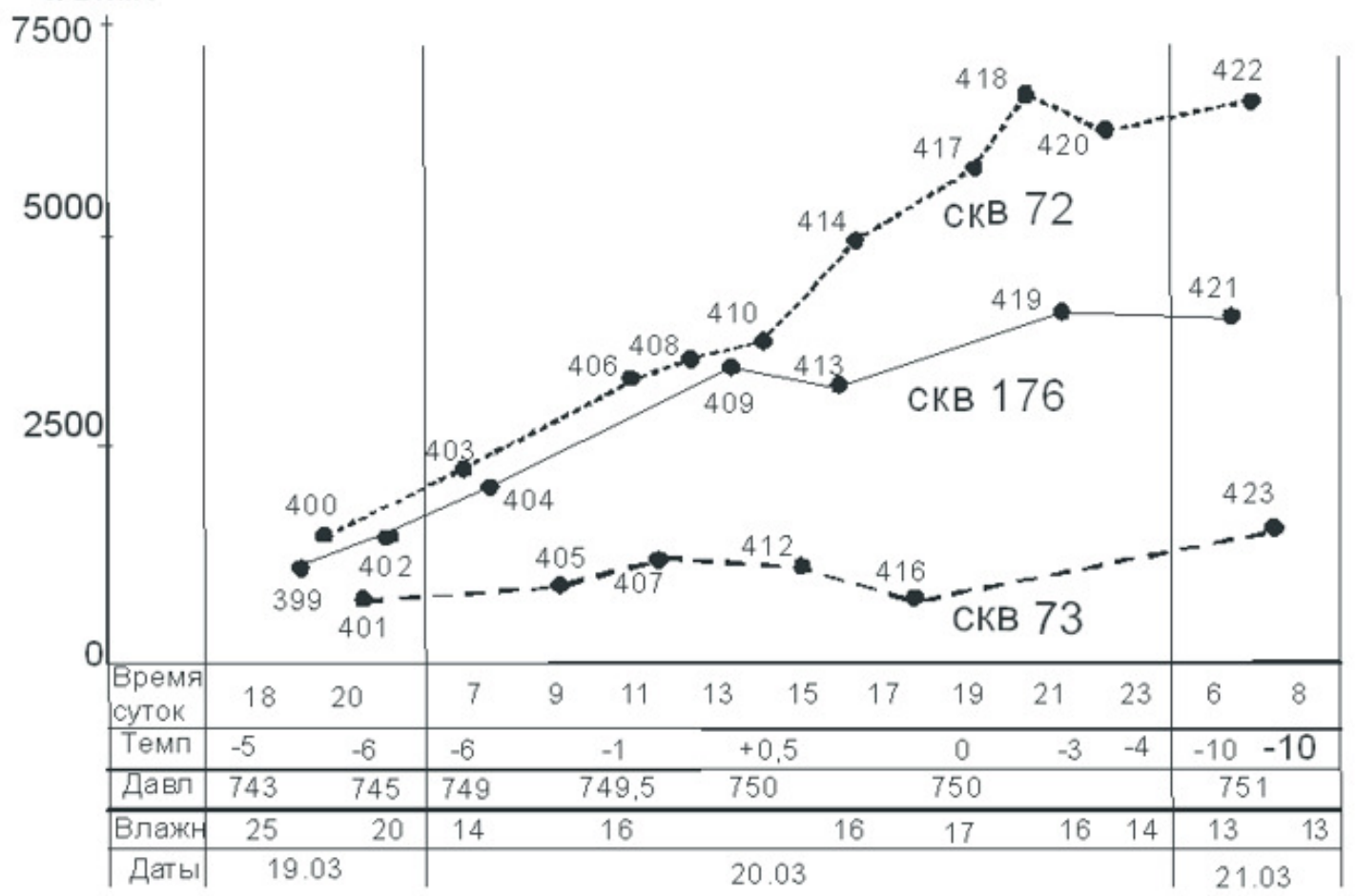

Puc. 4. Зависимость ОАР от времени суток (а) и метеоусловий в период мерзлого состояния грунта разной степенью уплотненности. Скв. 72 - рыхлый насыпной грунт из чернозема в траншее с водопроводом; Скв. 176 - грунт в естественном состоянии; Скв. 73 - насыпной грунт из суглинка. 

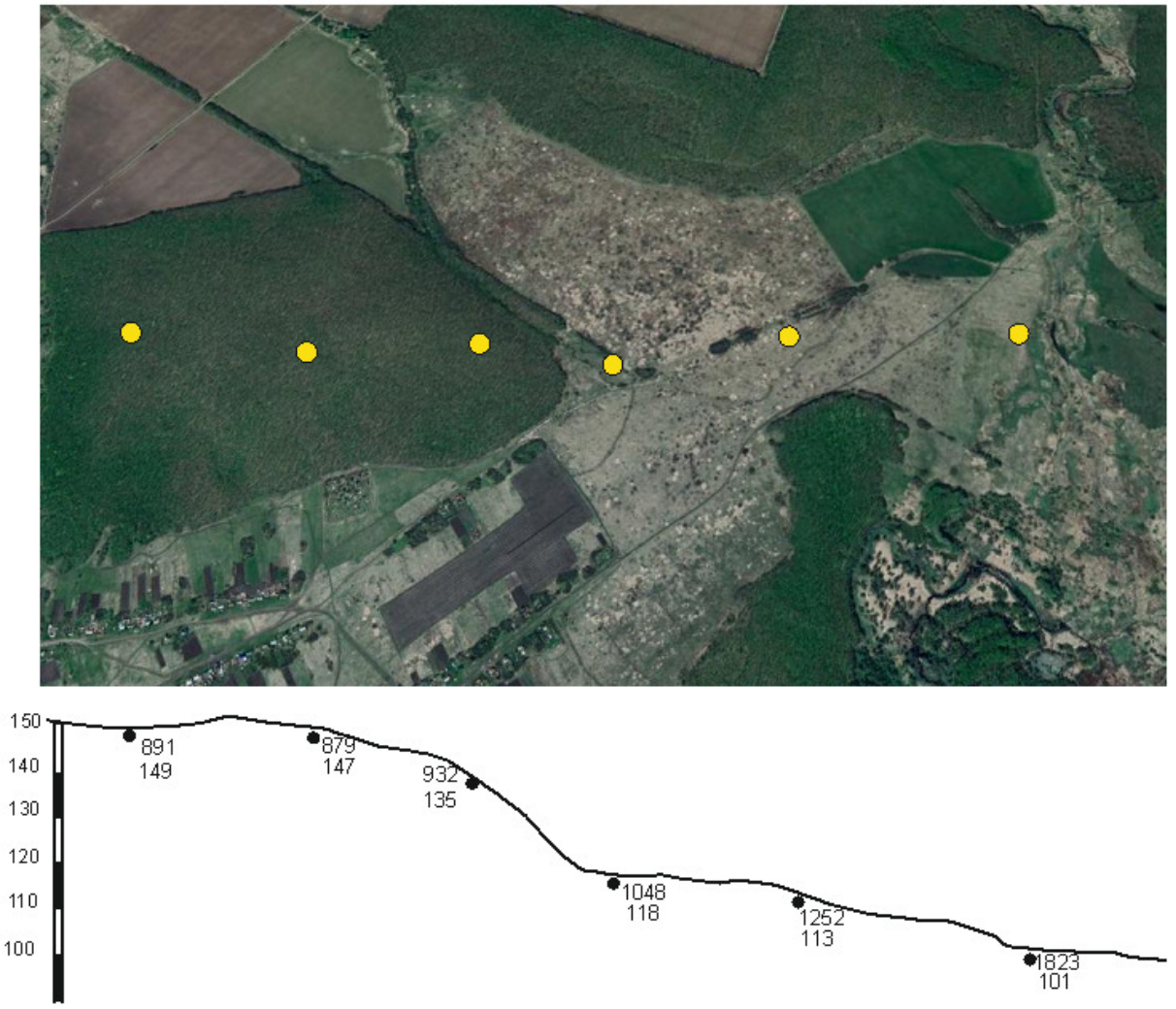

Рис. 5. Характер распределения значений ОАР по профилю мезорельефа. Спутниковая карта и профиль рельефа на приречном склоне правого берега р Анна в районе с. Старая Тойда. На профиле внизу в числителе значение активности, в знаменателе абсолютная отметка.

\section{5. Мониторинг динамики ОАР}

по геоморфологическим элементам ичиркуммента в районе с. Мечетка Бобровского района

В пределах более мелких замкнутых форм рельефа, картина может быть диаметрально противоположной - значения ОАР снижаются сверху вниз от бровки к днищу. Именно таким выглядит распределение ОАР на циркумментах [10]. Здесь в распределении неоднородностей радонового поля имеют значение уже склоновая дифференциация материала водными потоками в периоды снеготаяния и ливней. Весь сносимый с верхних частей тонкий материал скапливается у подножия склонов и на днище котловины. В результате в верхних частях циркумментов формируются кольцевые зоны из сравнительно крупного песка, практически лишенного почвенно-растительного покрова и хорошо проницаемого для восходящего потока радона. А вот более тонкий глинистый, да еще и более влажный осадочный материал в центральной части замкнутых котловин оказывается экраном для радона.

Такая картина устойчиво наблюдалась при мониторинге трех скважин, в июне и июле 2015 года на геоморфологических элементах циркуммента у с. Мечетка Бобровского района (скважина 171 на днище, скважина 172 у подножия склона и скважина 173 на песчаном валу).

Этот мониторинг позволил оценить и корреляционные зависимости между ОАР и метеоусловиями. К сожалению, погодные условия в этот период были достаточно стабильными, тем не менее, неко- торые закономерности достаточно очевидные. Исходные параметры и их статистические производные приведены в табл. 1 и 2.

Анализ графиков (рис. 6) показывает достаточно выраженную направленность изменений на протяжении всего периода наблюдений при этом противоположную на песчаном валу и других элементах. У подножия склона и на днище имело место в целом снижение значение ОАР и, напротив, наблюдался их рост на валу. Но, что интересно, на всех трёх скважинах ритмика изменений во времени полностью совпадает. Мониторинг данного объекта позволяет сделать анализ зависимости ОАР не только от положения на его геоморфологических элементах, но и от изменений физических параметров состояния атмосферы в утренние и вечерние часы.

Значимая корреляционная зависимость $(0,73)$ динамики изменений наблюдается между скважинами на днище и у подножия склона. Высокий коэффициент корреляции, между ними имеет место, как для утренних, так и вечерних замеров. Между валом и днищем она отрицательная или же, как значимая отсутствует. Это свидетельствует о качественных отличиях условий эксхаляции радона на днище и валу циркуммента. Объемная активность радона устойчива минимальная на днище циркуммента. Это может быть связано как с большей насыщенностью почвы влагой и вместе с тем с большей дисперсностью отложений и содержанием органики как хороших сорбентов. Количество орга- 
ники нарастало к середине лета, с чем можно и связывать тренд снижения ОАР. На песчаном валу к середине лета количество влаги снижалось, а вместе с ней и коллекторная способность песчаного грунта.

Таблица 1

Вариации значении ОАР по геоморфологическим элементам в циркумменте. (Общая выборка).

\begin{tabular}{|c|c|c|}
\hline \multicolumn{3}{|c|}{ Номера скважин } \\
\hline 171 & \multicolumn{1}{|c|}{172} & 173 \\
\hline Геоморфологические элементы & Вал \\
\hline Днище & $\begin{array}{l}\text { Подножие } \\
\text { склона }\end{array}$ \\
\hline \multicolumn{3}{|c|}{ Среднее ОАР в Бк/м3 } \\
\hline 1019 & \multicolumn{1}{|c|}{2426} & 2622 \\
\hline \multicolumn{3}{|c|}{ Коэффициент вариации ОАР } \\
\hline 27 15,0 & 15,7 \\
\hline Коэффициент корреляции ОАР между скважинами \\
\hline $171-172$ & $171-173$ & $172-173$ \\
\hline 0,73 & 0,13 & 0,1 \\
\hline Зависимость ОАР от атмосферных параметров \\
\hline Коэффициент корреляции с температурой \\
\hline$-0,35$ & $-0,34$ \\
\hline Коэффициент корреляции с давлением \\
\hline$-0,11$ & $-0,01$ \\
\hline Коэффициент корреляции с влажностью \\
\hline$-0,39$ & $-0,34$ \\
\hline \multicolumn{2}{|c|}{} \\
\hline
\end{tabular}

Таблица 2

Вариачии значении ОАР по геоморфологическим элементам в ичиркумменте. (Выборка, дифференцированная по утренним и вечерним замерам).

\begin{tabular}{|c|c|c|}
\hline \multicolumn{3}{|c|}{ Номера скважин } \\
\hline 171 & 172 & 173 \\
\hline Днище & Подножие склона & Вал \\
\hline \multicolumn{3}{|c|}{ Средние значения ОАР утром } \\
\hline 1137 & 2555 & 2814 \\
\hline \multicolumn{3}{|c|}{ Средние значения ОАР вечером } \\
\hline 901 & 2297 & 2432 \\
\hline \multicolumn{3}{|c|}{ Коэффициент корреляции по скважинам утро-вечер } \\
\hline 0,62 & 0,1 & $-0,32$ \\
\hline \multicolumn{3}{|c|}{$\begin{array}{c}\text { Коэффициент корреляции ОАР между скважинами } \\
\text { утром }\end{array}$} \\
\hline $171-172$ & $171-173$ & $172-173$ \\
\hline 0,6 & 0,08 & $-0,18$ \\
\hline \multicolumn{3}{|c|}{$\begin{array}{l}\text { Коэффициент корреляции ОАР между скважинами } \\
\text { вечером }\end{array}$} \\
\hline $171-172$ & $171-173$ & $172-173$ \\
\hline 0,87 & $-0,31$ & $-0,06$ \\
\hline \multicolumn{3}{|c|}{ Зависимость ОАР от атмосферных параметров } \\
\hline \multicolumn{3}{|c|}{ Утро } \\
\hline \multicolumn{3}{|c|}{ Коэффициент корреляции с температурой } \\
\hline 0,07 & $-0,11$ & $-0,15$ \\
\hline \multicolumn{3}{|c|}{ Коэффициент корреляции с давлением } \\
\hline$-0,51$ & $-0,39$ & 0,63 \\
\hline \multicolumn{3}{|c|}{ Коэффициент корреляции с влажностью } \\
\hline$-0,44$ & 0,1 & $-0,16$ \\
\hline \multicolumn{3}{|c|}{ Вечер } \\
\hline \multicolumn{3}{|c|}{ Коэффициент корреляции с температурой } \\
\hline$-0,13$ & $-0,03$ & $-0,65$ \\
\hline \multicolumn{3}{|c|}{ Коэффициент корреляции с давлением } \\
\hline 0,30 & 0,19 & $-0,32$ \\
\hline \multicolumn{3}{|c|}{ Коэффициент корреляции с влажностью } \\
\hline 0,54 & $-0,06$ & $-0,28$ \\
\hline
\end{tabular}

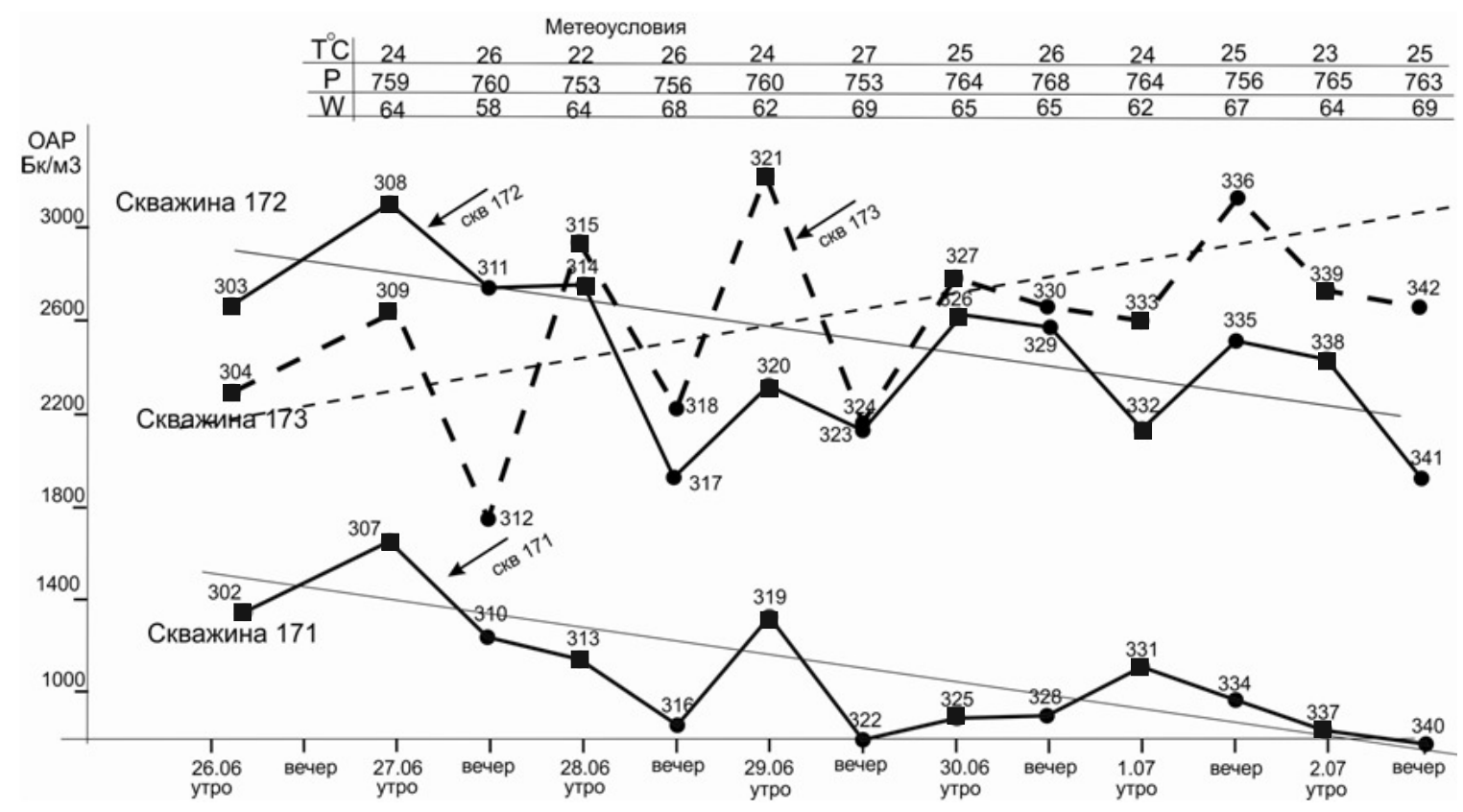

Pис. 6. Графики вариаций ОАР и линейные тренды в скважинах на полигоне «Мечетка». Квадраты - утренние замеры, кружки - вечерние, цифры над кружками - номера проб в базе данных. Положение скважин в циркумменте: $171-$ днище; $172-$ подножие склона; 173 - вал. 


\section{Заключение}

Радоновый метод может служить инструментом для выявления неблагоприятных и опасных для постоянного пребывания людей в очагах загрязнения, но корректное применение его требует больших затрат времени. Как показывают результаты проведенных нами режимных наблюдений, имеют место вариации разной природы, при которых амплитуда их меняется в разы. Любые даже близко расположенные между собой точки земной поверхности могут устойчиво сохранять свою индивидуальность по интенсивности радоновой эксхаляции. Это показывает, что радоновый метод позволяет получать вполне объективную и ценную информацию. При этом велик и информационный «шум», природу которого не всегда сразу можно понять, следовательно, и отфильтровать. Абсолютные одноразовые средние значения даже полученные в течение нескольких часов замеров, как это рекомендуется для «Комплекса $01 »$, всё равно не могут служить надежным оценочным критерием, в качестве которого нормативами рекомендуется эквивалентная среднегодовая активность. Требуется применение коэффициента вариации, но обосновать его расчетами - задача не менее трудоемкая. Поэтому разработчики нормативов в принципе не запрещают использовать экспресс-методику определения ОАР в почве, но при этом опасной предлагается считать активность при значении превышающим более 40 кБк/м3. Но это очень большая активность, она больше верхнего предела, возможного для такого широко применяемого в инженерно-экологических изысканияХ прибора серии РРА-01. В перспективе необходимо разрабатывать методики типизации условий, разработать систему поправочных коэффициентов для всех факторов, влияющих на эксхаляцию грунтов, что позволит сократить трудоемкий и длительный процесс проведении замеров.

Что касается возможностей выявления с помощью радонового метода структурных неоднородностей геологического строения, то и здесь у исследователей также нет однозначного ответа. Свое видение данной проблемы на основании собственного опыта авторы надеются изложить в следующей статье.

\section{ЛИТЕРАТУРА}

1. МУ. 2.6.1.2398-08. Методические указания 2.6.1 Ионизирующее излучение, радиационная безопасность. Радиационный контроль и санитарно-эпидемиологическая оценка земельных участков под строительство жилых домов, зданий и сооружений общественного и производственного назначения в части обеспечения радиационной безопасности. 2008.

2. СанПиН 2.6.1.2523-09 «Нормы радиационной безопасности (НРБ-99/2009). 2009.

3. Микляев, П. С. Научные основы оценки потенциальной радоноопасности платформенных территорий: диссертация доктора геолого-минералогических наук: 25.00.36 / П. С. Микляев // Институт геоэкологии им. Е. М. Сергеева PAH, 2015. - $307 \mathrm{c}$.

4. Морозов, В. Н. Математическое моделирование атмосферно-электрических процессов с учетом влияния аэрозольных частиц и радиоактивных веществ / В. Н. Морозов. СПб.: РГГМУ, 2011. - 253 с.

5. Паровик, Р. И. Математическая диффузионная модель массопереноса радона $\left({ }^{222} \mathrm{Rn}\right)$ в грунте и его эксхаляции в приземный слой атмосферы / Р. И. Паровик, И. А. Ильин, П. П. Фирстов // Вестник Краунс. Сер.: Науки о земле, 2006. - № 1. - С. 110-114.

6. Семинский, К. Ж. Радоновая активность разнотипных разломов земной коры (на примере Западного Прибайкалья и Южного Приангарья) / К. Ж. Семинский, А. А. Бобров // Геология и геофизика. - 2009. - Т. 50. - № 8. - С. 881-896.

7. Сухоруков, М. В. Особенности миграции радона ${ }^{222} \mathrm{Rn}$ по нарушенностям среды горного массива во времени на малых глубинах / М. В. Сухоруков // Неделя горняка. - 2010. C. $372-374$.

8. Уткин, В. И. Радон как индикатор геодинамических процессов / В. И. Уткин, А. К. Юрков // Журнал «АНРИ». 2008. - № 2 (53). - С. 10-17.

9. Никифоров, Д. В. Геоэкологическая оценка радоноопасности территории Воронежской области / Изв. ВУЗов. Геол. и разведка. - 1989. - №1. - С. 133-136.

10. Ильящ, Д. В. Циркумменты как особый вид экологогеологических систем / Д. В. Ильяш, В. В. Ильяш // Вестн. Воронеж. Гос. ун-та. Сер. Геология. - 2015. - № 1. - С. 214 218.

11. Ильям, В. В. Реальные и потенциальные геоэкологические риски в Новохоперском районе / В. В. Ильяш, Д. В. Ильяш, А. А. Валяльщиков // Труды Хоперского государственного заповедника, 2016. - Вып. 10. - С. 52-59.

12. Косинова, И. И. Новохоперская геоактивная зона - ее прошлое и настоящее / И. И Косинова, В. В. Ильяш, Н. Д. Разиньков // Вестн. Воронеж. Гос. ун-та. Сер. Геология. 2016. - № 4. - С. 167-170.

13. Косинова, И. И. Оценка природы экологических рисков на площади разработки месторождений сульфидных руд (Воронежская область)// И. И Косинова, В. В. Ильяш, Н. Д. Разиньков. Разведка и охрана недр, М. - 2018. - вып. 1. C. $12-18$

14. Алексеенко, В. А. Экологическая геохимия. / В. А. Алексеенко. - М. «Логос», 2000. - 626 с.

\section{Воронежский государственный университет}

Ильяш Валерий Владимирович, дочент кафедры экологической геологии ВГУ

E-mail:vvikii@mail.ru; Тел.: 82495467

ООО «Инженерная геодезия и топография» (ИГИТ)

Ильяш Дмитрий Валерьевич, главный эколог Тел.: 89192445971
Voronezh State University

Ilyash V. V., the docent of the Ecological Geology Department E-mail:vvikii@mail.ru

Tel.: 82495467

LLC «Engineering Geodesy and Topography» (IGIT)

Ilyash D. V., main ecologist

Tel.: 89192445971 